\title{
Procedural Priorities of the Pork Loin Supply Chain
}

\author{
Matheus Dhein Dill', Jean Philippe Palma Revillion², Júlio Otávio Jardim Barcellos ${ }^{3}$, \\ Eduardo Antunes Dias ${ }^{4}$,Thomaz Zara Mércio ${ }^{5}$,Tamara Esteves de Oliveira ${ }^{6}$
}

\begin{abstract}
The pork meat production industry is facing new challenges as a consequence of consumers' expectations regarding the quality and safety of food products. For the present study, experts and consumers in Rio Grande do Sul State, Brazil were interviewed to identify the attributes of pork loin that need to be improved. Consumers have particular concerns about the juiciness, fibrousness, and portion size of the meat, the diversity of cuts and safety and animal welfare. The supply chain was also analyzed in order to verify the procedural priorities that need to be improved in order to meet the demands of consumers. Experts were interviewed using the quality function deployment methodology. The findings of the study indicate that, improvements must be made in the production sector in terms of animal handling and transportation. In the processing sector, improvements are required regarding slaughter control of PSE and DFD, the development of new packaging, and product fractionation. The requirements in the distribution sector relate to information campaigns for consumers to diffuse the nutritional characteristics of pork loin and in the product safety through sanitary inspection.
\end{abstract}

Keywords: meat; product development; QFD; quality; technological priority; consumers; supply chain; pork.

\footnotetext{
1,2,3,4,5,6 Centro de Estudos e Pesquisas em Agronegócios (CEPAN). Universidade Federal do Rio Grande do Sul (UFRGS). Av. Bento Gonçalves, 7.7I 2, 9I.540-000, Porto Alegre, RS, Brazil. Phone: +55 5 I 3308-6586. e-mail: 'matheusdill@hotmail.com
} 


\section{Introduction}

Consumers analyze the quality of a product by detecting and ranking its quality indicators. In food, those indicators are represented by intrinsic and extrinsic attributes that are often quite difficult to measure (Poulsen, 1996; Grunert, 2002). Moreover, these attributes are interdependent and diverge according to the meat's morphological structure, chemical composition, microbial contamination, sensorial properties, procedure's hygiene, nutritional value (Pardi et al., 200I), convenience for cooking, and the properties of its processing (Canever, 2006).

Negative perceptions related to sanitary concerns affect the consumption of pork due to the lack of origin information and cultural issues (Faria et al., 2006; Bezerra et al., 2007; Farias et al., 2012). Pork consumption is also affected by new requirements related to certification, traceability, animal welfare, sustainability of production systems (Verbeke et al., 20 I0; Barcellos et al., 20l la), the practicality and convenience of the product (Barcellos et al., 20 I lb), and healthrelated consuming habits (Grunert, 2006).

In this context, the importance of analyzing the attributes that consumers consider to have high priority has been highlighted because the supply chain will only be able to improve product quality when consumer requirements (both intrinsic and extrinsic) are considered together during the development process of the product (Dekker and Linnemann, 1998; Sijtsema et al., 2002). In the same way, tools that allow the analysis of important attributes while identifying improvement actions, such as the quality function deployment (QFD) method (Akao, 1972; Miguel et al., 2007; Jaiswal, 20I2), are important for effective supply chain management (Zarei et al., 20I I).

The QFD methodological method approach is driven by and directed towards consumers; it captures the costumers' needs, expectations and preferences, translating them to different production processes in order to detect problems and possible solutions to ensure the quality of the product. Few studies have analyzed the intrinsic and extrinsic attributes that consumers consider relevant to a specific cut in pork. Thus, the pork loin, which represents approximately 10 percent of the live weight of the animal, was chosen as the object of study to be considered as a traditional cut with high commercial value. It is also appropriate to restrict the search to consumers in the state of Rio Grande do Sul because, according to Schlindwein and Kassouf (2006), the consumption of pork in Brazil is concentrated in the south, although most of this demand is in the form of sausage and ham.
To understand the attributes that are considered relevant to consumers of pork loin, and also to analyze possible strategies for improving this chain, the present study has defined the attributes most valued by consumers through interviews with experts and market research. Based on this information, using the methodological basis of QFD and expert interviews, possible procedural adaptations with which to meet the demands were analyzed.

\section{Material and Method}

In the first step of the research, through a literature review and the contributions of nine experts, the attributes of pork loin that consumers considered relevant were identified. With this information a questionnaire was elaborated and validated through conducting a pre-test with 10 consumers. The questionnaire was sent by email and data was collected using the Sphinx Léxica version 5.0 software program. The sample was composed of 392 residents of the Brazilian state of Rio Grande do Sul, selected randomly, as indicated by Cheng et al. (1995).

For the sample characterization and identification of consumption habits (age, family size, gender, educational level, frequency of consumption, presentations of the cuts, cooking preference, and place of purchase), closed questions were used and the qualitative variables were described based on their absolute and relative frequency.

The sensorial aspects, nutritional and food safety, certification and origin, practicality and convenience were analyzed using closed questions according to a I-5 Likert scale, with rates ranging from 0 to 100 . To analyze all groups of questions, analysis of variance and a randomized block design was used, complemented by the Tukey test at a significance level of 5 percent.

In the second step, the quality matrix of the QFD was used to analyze the relationship between consumer needs (identified at the first step) and the processes to be improved in the supply chain. Therefore, the sectors of the supply chain were added to the matrix (production, transportation, processing, and distribution) as suggested by Canever (2006). This enabled us to measure the responses of consumer expectations in the technical and procedural characteristics of this supply chain and use them to determine the key factors interfering product quality (Cheng et al., 1995).

The main characteristics of pork loin were selected on the above basis and, from the literature review, the improvement processes in the supply chain were discerned, which was used to elaborate the QFD matrix. Four experts from different fields were interviewed to identify critical points. The experts identified the relationship between attribute and 
process by allocating points based on the following scale: strong $=9$ points, average $=3$, poor $=1$.

The sum of the scores given by the experts was then inserted in the matrix. The procedures that achieved more than 22 points were considered as critical procedures. The priority technique was also calculated as the sum of all scores in the line in order to infer the capability of one attribute to be improved from intervention procedures. This dimension was chosen as an indicator to explain the factors that should be improved in order to meet consumers' demand, based on suggestions of the experts and literature review.

\section{Results and discussion}

First step - attributes of pork loin relevant to consumers The sample consisted of 392 pork consumers living in Rio Grande do Sul State, 50.8 percent of whom were male and 49.2 percent were aged between 21 and 30 years. Most of the consumers were university graduates and post-graduates. The largest portion of respondents shares a house with one other person, followed by those who live alone (Table I).

The majority of respondents preferred rib cut, followed by pork loin. Most consumers choose chilled pork loin, and prefer to purchase it at supermarkets and hypermarkets (Figure I); this supports the research conducted by Barcellos et al., (20l Ib).

\begin{tabular}{|c|c|c|c|c|c|c|c|c|}
\hline Age (years) & No. & $\%$ & Education & No. & $\%$ & $\begin{array}{c}\text { Number of people in } \\
\text { the household }\end{array}$ & No. & $\%$ \\
\hline $21-30$ & 193 & 49.2 & Post-graduate & 192 & 49 & 2 & 126 & 32.1 \\
\hline $4 I-50$ & 70 & 17.9 & Graduate & 139 & 35.4 & I & 108 & 27.6 \\
\hline $31-40$ & 65 & 16.6 & High school & 32 & 8.2 & 3 & 74 & 18.9 \\
\hline $51-60$ & 39 & 9.9 & Technician & 20 & 5.1 & 4 & 47 & 12 \\
\hline$<20$ & 11 & 2.8 & Elementary school & 4 & I & 5 & 19 & 4.8 \\
\hline$>60$ & $\mathrm{II}$ & 2.8 & None & 0 & 0 & $>5$ & 5 & 1.3 \\
\hline Not answered & 3 & 0.8 & Not answered & 5 & 1.3 & Not answered & 13 & 3.3 \\
\hline Total & 392 & 100 & Total & 392 & 100 & Total & 392 & 100 \\
\hline
\end{tabular}

Table I. Characterization of the respondents in Rio Grande do Sul State, Brazil.

\begin{tabular}{|c|c|c|c|c|c|}
\hline Variables & $N^{\circ}$ & $\%$ & Variables & $\mathrm{N}^{\circ}$ & $\%$ \\
\hline \multicolumn{2}{|l|}{ Favorite pork cut } & & Preparation methods & & \\
\hline Rib & 136 & 34.7 & Roasted & 180 & 45.9 \\
\hline Loin & 116 & 29.6 & Barbecued & 146 & 37.2 \\
\hline Ham & 48 & 12.2 & Boiled & 61 & 15.6 \\
\hline Tender loin & 44 & 11.2 & Not answered & 5 & 1.3 \\
\hline Pork chop & 21 & 5.4 & Total & 392 & 100 \\
\hline Neck & 15 & 3.8 & Consumption frequency & & \\
\hline Other & 5 & 1.3 & Less than once a month & 152 & 39.3 \\
\hline Not answered & 7 & 1.8 & More than once a month & $13 \mid$ & 33.9 \\
\hline Total & 392 & 100 & Once a week & 104 & 26.9 \\
\hline \multicolumn{2}{|c|}{ Location of choice for buying } & & Total & 387 & 100 \\
\hline Super/hypermarket & 280 & 71.4 & Pork loin presentation form & & \\
\hline Meat boutique & 44 & 11.2 & Cooled & 293 & 74.7 \\
\hline Local Market & 30 & 7.7 & Frozen & 77 & 19.6 \\
\hline Direct from farmers & 27 & 6.9 & Frozen meals (pre-prepared) & 13 & 3.3 \\
\hline Fairs & 3 & 0.8 & Not answered & 9 & 2.3 \\
\hline Not answered & 8 & 2.0 & Total & 392 & 100 \\
\hline Total & 392 & 100 & & & \\
\hline
\end{tabular}

Figure I. Pork meat consumers' opinions regarding pork loin in Rio Grande do Sul State, Brazil.

ISSN: 07 I8-2724. (http://www.jotmi.org)

Journal of Technology Management \& Innovation (c) Universidad Alberto Hurtado, Facultad de Economía y Negocios. 
Regarding the preparation habits, consumers prioritize the use of conventional ovens ( 45.9 percent). Once pork loin consumption habits have been established, the information regarding the consumer's profiles may be applied to their benefit (Figure 1). Therefore, the low preference for preprepared frozen meals may be related to the low level of satisfaction resulting from lack of diversity of pre-prepared products available for consumption (5I.2 points) (Table 2 ).

Among "sensorial aspects variable group", most consumers considered pork loin flavor to be pleasant; this was represented by an average of 90.0 points - the statistical index was higher when compared to ease of chewing, softness, and aroma, which do not differ statistically. Meat fibrousness (the lowest average, at 56.9 points) and pork loin's juiciness pre- sented low scores. Becker (2002) and Aaslyng et al., (2007) also stated that low juiciness had a negative impact on consumer's satisfaction.

The evaluation of the importance of the "certification and sanitary aspects variable group" indicates that animal sanitary aspects are the most important requirement in this section. The Federal Inspection System (SIF) and trust in the retails were also considered relevant. Consumers also considered respect for animal welfare standards, the environmental impact generated by the productive system, the nutritional information on the packing, traceability, and certificate of origin to be important. Verbeke et al. (2010) emphasized that population awareness regarding ethical consequences of intensive animal production is increasing.

\begin{tabular}{|c|c|c|c|c|c|}
\hline Variables & $\mathrm{N}$ & Mean & Standard Deviation & Min. & Max \\
\hline \multicolumn{6}{|l|}{ Sensorial aspects } \\
\hline The flavor of pork loin is good & 386 & $90.0^{\mathrm{A}}$ & 16.7 & 0 & 100 \\
\hline Pork loin is easy to chew & 386 & $84.8^{\mathrm{B}}$ & 20.5 & 0 & 100 \\
\hline Pork loin is tender & 382 & $84.6^{\mathrm{B}}$ & 21.4 & 0 & 100 \\
\hline Pork loin aroma is pleasant & 385 & $84.0^{\mathrm{B}}$ & 20.9 & 0 & 100 \\
\hline Pork loin is easy to digest & 380 & $64.2^{\mathrm{C}}$ & 27.9 & 0 & 100 \\
\hline Pork loin is juicy & 385 & $62.0^{\mathrm{C}}$ & 33.9 & 0 & 100 \\
\hline Pork loin is fibrous & 384 & $56.9^{\mathrm{D}}$ & 31.8 & 0 & 100 \\
\hline \multicolumn{6}{|l|}{ Certification and sanitary aspects } \\
\hline Animal sanitary aspects & 384 & $93.5^{\mathrm{A}}$ & 14.7 & 0 & 100 \\
\hline Federal Inspection Service (SIF) & 383 & $91.3^{\mathrm{AB}}$ & 18.7 & 0 & 100 \\
\hline Confidence in the retailer & 381 & $88.6^{\mathrm{B}}$ & 16.2 & 25 & 100 \\
\hline Production system within the standards for animal welfare & 380 & $83.0^{\mathrm{C}}$ & 23.6 & 0 & 100 \\
\hline Environmental protection & 382 & $81.8^{\mathrm{CD}}$ & 24.0 & 0 & 100 \\
\hline Nutritional information on the package & 381 & $77.8^{\mathrm{DE}}$ & 26.7 & 0 & 100 \\
\hline Traceability & 383 & $76.3^{\mathrm{EF}}$ & 27.6 & 0 & 100 \\
\hline Certificate of origin & 381 & $72.9^{\mathrm{FG}}$ & 29.8 & 0 & 100 \\
\hline Brand & 380 & $70.9^{\mathrm{G}}$ & 23.9 & 0 & 100 \\
\hline Organic production & 381 & $61.7^{\mathrm{H}}$ & 32.2 & 0 & 100 \\
\hline \multicolumn{6}{|l|}{ Practicality and convenience } \\
\hline Pork loin availability at the retailer & 382 & $70.0^{\mathrm{A}}$ & 22.6 & 0 & 100 \\
\hline Convenience (easy to prepare) & 384 & $67.0^{\mathrm{A}}$ & 21.6 & 0 & 100 \\
\hline The diversity of recipes/preparation methods & 384 & $62.4^{\mathrm{B}}$ & 23.4 & 0 & 100 \\
\hline Size of portions cooled/frozen & 380 & $59.7^{\mathrm{BC}}$ & 23.0 & 0 & 100 \\
\hline Price & 380 & $58.0^{\mathrm{C}}$ & 23.0 & 0 & 100 \\
\hline Diversity of pre-prepared products & 381 & $51.2^{\mathrm{D}}$ & 23.3 & 0 & 100 \\
\hline
\end{tabular}

Table 2. Intrinsic and extrinsic attributes relevant for pork loin consumers in Rio Grande do Sul State, Brazil. 
Regarding the respondents' degree of satisfaction related to the practicality and convenience of available pork loin cuts, consumers expressed some satisfaction with the retail availability of the product and to its preparation easiness. On the other hand, consumers resented the low product diversity of pre-prepared products, the price, and portion size (Table 2).

Pork loin is typically sold in weights of around $1.5 \mathrm{~kg}$, which may cause some consumer dissatisfaction, since most respondents live alone or with only one person. In this context, Brazil is experiencing a decrease in the number of individuals that compose the families (Ferrario and Cunha, 2012). This situation is an opportunity to develop new products for specific consumer groups.

The association of pork loin consumption with health problems occurred for 33.4 percent of indications regarding transmission of diseases, 20.2 percent of cases of increased cholesterol, 14.5 percent of excess calorie consumption, and 10.5 percent of heart failure (Table 3). These results, combined with the fact that most respondents have graduate and undergraduate degrees, indicates that the lack of information affects pork consumption negatively. These erroneous associations of pork consumption with health problems were also documented by Bezerra et al. (2007), Silva and Silva (2009), Santos et al., (20I I), and Farias et al., (2012).

In this context, it is vital to emphasize that pork inspection prevents worm contamination. An example of effective marketing is the fact that 94.4 percent of the respondents still consumed pork meat after the influenza $A(\mathrm{HINI})$ episode, which was misnamed as swine flu. Therefore, the clarification made by the media was effective because it was consistently reported that the virus is not transmitted in properly cooked pork meat (OIE, 2009).
However, there is a need to improve the pork loin quality to better suit consumers. In this approach, the attributes considered as priorities were chosen to be part of the second research stage: succulence, fibrousness, portion size, and variety of preparation methods. It was also identified that consumers consider respect for animal welfare practices to be important, as well as strategic actions applied to improve product image related to the trust and safety of the food. Barcellos et al. (20l lb) stated that understanding pork consumer's perceptions creates opportunities to improve and develop new products in the supply chain.

\section{Second step - procedural priorities}

When analyzing the attributes that consumers considered important and relating them to the procedural intervention identified by the experts, the product image is the first factor that requires attention (322 points) (Figure I). This could be caused by consumers' misperceptions about the effects of pork on human health.According to Grunert (2006), consumers' perceptions of extrinsic attributes, especially pork meat image, is connected to two events: the awareness of the relationship between diet and health, and by the consumer interest in the product information and origin of the food (Grunert, 2006). Following this approach, information transparency related to pork production (traceability and certification) is important to address possible misconceptions regarding product quality (Barcellos et al., 20 I la).

Thus, the intervention points identified by the experts to improve product image related to food safety are directly related to the cold chain (30 points), both in the processing and distribution. Although large industries have effective temperature control systems, small and medium industries still present complications in this requirement. In the distribution sector, the problem lies with the retail shelves, which are often not set at the proper temperature throughout the day. According to Brasil (1996), the temperature in the center of the cut must not exceed $7^{\circ} \mathrm{C}$.

\begin{tabular}{lcc}
\hline \multicolumn{1}{c}{ Variables } & $\mathrm{N}$ & $\%$ \\
\hline Not associated with any & 193 & 49.2 \\
health problems & 131 & 33.4 \\
Transmission of diseases & 79 & 20.2 \\
Increased cholesterol & 57 & 14.5 \\
Excess calories & 41 & 10.5 \\
Heart diseases & 8 & 2.0 \\
Not answered & 392 & 100 \\
Total & & \\
\hline
\end{tabular}

Table 3.Association of pork loin consumption to health problems. Note: Respondents had the option to select more than one answer.

ISSN: 07 I8-2724. (http://www.jotmi.org)

Journal of Technology Management \& Innovation (c) Universidad Alberto Hurtado, Facultad de Economía y Negocios. 
The standards imposed by governmental inspection services ensure that safe food is presented to consumers. Processing, distribution, and marketing practices are supported by the Regulation of Industrial and Sanitary Inspection of Animal Origin Products (RIISPOA), and also by the Technical Regulations and Establishment of Production Standards of Identity and Quality (RTPIQ).

To improve consumer perceptions, experts also suggested that informational campaigns be conducted at the distribution spot (36 points) and in educational media informing the quality standards regulated by the government. In conjunction with this, promotional campaigns were suggested ( 24 points) to spread pork loin consumption, and promotional campaigns with health professionals to highlight the nutritional characteristics of pork loin.

As presented in the matrix, product image is also related to the packaging (30 points). Therefore, packaging must contain information with strong visualization that highlights the nutritional values and the safety of the product.Verbeke (2010) also emphasized the relevance of the nutritional information and the potential role of packaging and labeling. The fact that increasing the transparency in food information can promote changes in consumption habits has led some industries to reformulate their products; for example, processed foods with less fat and nitrate.
Another strategy is to develop packaging with moisture control and removal of oxygen and carbon dioxide in order to increase the product shelf life. The packaging may also contain a system to monitor the storage and transportation conditions by applying time-temperature sensors and radio frequency identification (RFID) technology to provide enhanced transparency in the production processes (Kerry et al., 2006).

Juiciness was the second attribute with more procedural intervention (242 points). To improve this attribute, experts have highlighted the need for genetic improvement (30 points) to increase intramuscular fat, as well as special attention in handling the grower-finisher pigs (24 points). To improve consumer acceptability, animals should be between 100 and $110 \mathrm{~kg}$ when they are slaughtered and should have back fat thickness between $15 \mathrm{~mm}$ and $20 \mathrm{~mm}$. In a sensory analysis performed by Alonso et al., (2010), consumers gave higher scores for juiciness when the meat had higher intramuscular fat and high notes for fibrousness when pork meat had low intramuscular fat. The vehicles suitability to transport the animals (30 points) and humane slaughter (30 points) must be prioritized in order to minimize the appearance of pale, soft, exudative (PSE) and dark, firm and dry (DFD) meat in the processing sector (36 points). These factors are directly related to animal welfare, which affects the quality of the product.

\begin{tabular}{|c|c|c|c|c|c|c|c|c|c|c|c|c|c|c|c|c|c|c|c|c|c|c|}
\hline \multirow{2}{*}{\multicolumn{20}{|c|}{\begin{tabular}{r|r}
\multicolumn{2}{|c}{ PORK LOIN SUPPLY CHAIN } \\
Trans
\end{tabular}}} & & & \\
\hline & & & & & & & & & & & & & \multicolumn{3}{|c|}{ Processing } & Distribution & & & & & & \\
\hline & & 㟒 & שֶ & 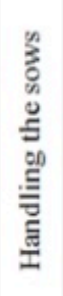 & 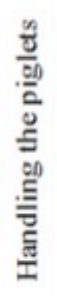 & 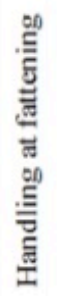 & 莺 & 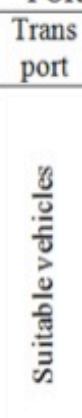 & 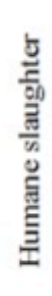 & है & & $\begin{array}{l}\text { 产 } \\
\frac{0}{0} \\
\frac{\partial}{0}\end{array}$ & 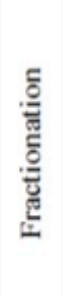 & 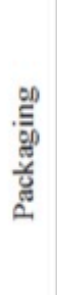 & 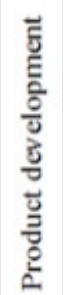 & 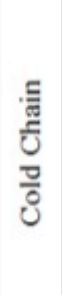 & 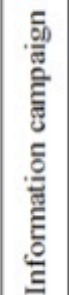 & 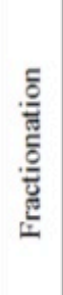 & 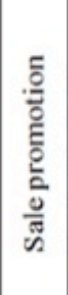 & 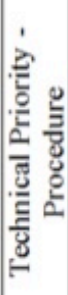 & 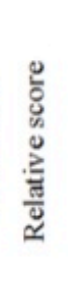 & 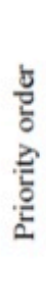 \\
\hline \multirow{2}{*}{ 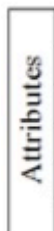 } & Product image & 16 & 8 & 11 & 11 & 11 & 13 & 13 & $22^{*}$ & 13 & & $30^{*}$ & 16 & $30^{*}$ & 15 & $30^{*}$ & $36^{*}$ & 15 & $24^{*}$ & 322 & 24,5 & 1 \\
\hline & Juiciness & 5 & $30^{*}$ & 5 & 6 & $24^{*}$ & 6 & $30^{*}$ & $30^{*}$ & 6 & & 16 & 3 & 15 & 3 & 10 & 10 & 3 & 4 & 242 & 18,5 & 2 \\
\hline
\end{tabular}

Figure 2. Matrix of critical points* in the production chain procedures of loin pork according to expert opinion in Rio Grande do Sul, Brazil.

ISSN: 07 I8-2724. (http://www.jotmi.org)

Journal of Technology Management \& Innovation (c) Universidad Alberto Hurtado, Facultad de Economía y Negocios. 
Consumers considered animal welfare to be important, and it was also the third priority technique ( 230 points) identified by the experts. During the interviews, it was noted that there lack of commitment of the creators and industry to improve animal welfare, mainly due the increased costs of production. Measures in the productive sector included management of piglets, sows and finishing animals (30 points), and the correct feeding ( 24 points), introduction of objects (chains and toys) to break monotony and increase physical space are needed to improve animal welfare; this corroborates with Beattie et al. (2000).

It has also been stated that sows, in general, created in individual cages with limited space, prevent movement, resulting in stress, behavioral problems, and lower piglet production (Zanella et al., 1996; O'Connell et al., 2004). The sows' accommodation in collective pens promotes comfort and animal welfare, which reflects positively on piglets' farrowing (Silva et al., 2008).

Piglet management (30 points) was identified as weak in terms of animal welfare because of practices such as teeth clipping, surgical castration without anesthesia, and caudectomy. However, teeth clipping is performed to reduce injuries in the sows during breastfeeding and cannibalism caused by the restricted space, which may occur if the caudectomy is not performed.

The experts suggested immunocastration to minimize the suffering caused by surgical castration. However, according to Santiago et al. (20I2), this technique leads animals to exhibit sexually aggressive behavior, causing fights in collective stalls. This in turn can stress the animals in the stalls near slaughtering, increasing the incidence of PSE meat.

With regard to animal transport (36 points), the interviews revealed that many trucks are inappropriate because they offer no protection to animals against the wind, rain and sun; and carry an excessive load of animals.According to the OIE (20I I), the truck must have an area of $0.51 \mathrm{~m}^{2} / 100 \mathrm{~kg}$ animal and the transportation must be calm and at low temperatures, avoiding combining animals from different lots.

Regarding humane slaughter (36 points), carbon dioxide chambers were suggested for desensitizing the animals. Another proposed solution has been to use a device that automatically measures the weight of the animal and calculates the optimal voltage and amperage for the desensitization. Bertoloni et al. (2006) observed that electrical desensitization systems were more stressful to the animals than gas desensitization (CO2) systems. Stressed animals have reduced glycogen levels in their muscles at the time of slaughter, leading to DFD meat, which increases contamination. This glycogen deficiency is caused by a prolonged fasting, excitement, fights, and electric shocks (Pardi et al., 200I). Furthermore, the resting period before slaughter should be between six and eight hours in order to minimize the occurrence of PSE (Santiago et al., 20I2).

Experts considered consumer dissatisfaction with portion size and low product diversity at the supermarket as the fourth and fifth characteristics for interventions (202 and 197 points, respectively). The orientation to fractionation should be performed both in processing and in retail (36 points). To meet this demand, it was suggested that the portions have around 300 grams, since the number of people cohabitating in the same house is decreasing in Brazil.

In the processing sector, packaging (27 points) was related to portion size, especially to facilitate cooking. The use of crystallized PET trays (CPET) was suggested for its resistance to temperatures between $-40^{\circ} \mathrm{C}$ and $220^{\circ} \mathrm{C}$, enabling storage and microwave preparation (Ito, 2009). Regarding the diversity of the pork loin supply chain, minimal product variety was identified at the retail stage. Therefore, the development of new products is the procedure that needs the most attention (36 points). In general, pork loin should be easy to prepare, practical, pre-made, and available for both microwave and conventional cooking. Other suggestions were to add condiments and fillings to ensure flavor and juiciness. Barcellos et al. (20 I la) stated that consumers expect a greater variety of pork loins cuts, which should increase its convenience.

Pork loin's fibrousness had the lowest relationship of all interventions (1 18 points) along the supply chain, and was therefore seen as an attribute that was highly difficult to improve. This issue is related to the producing sector, specifically in genetic selection ( 24 points). It was also noted that the fibrousness may be connected to tenderness and juiciness, which is influenced by the ability of meat to retain water after slaughter and also through the levels of intramuscular fat. Crawford et al. (2010) emphasized that genetic selection with the aim of increasing meat production has shown negative impact on palatability. Thus, the processes that influence $\mathrm{pH}$ of the meat, as well as the factors related to intramuscular fat (breed, slaughter age, sex, and feeding), should be improved.

In addition, advances in nutrition, breeding and animal genetics will open new perspectives for the pork meat industry. Technological innovations have increased the possibilities of product differentiation, and consumers will influence the direction of these developments (Garnier et al., 2003). 


\section{Conclusions}

The most relevant quality attributes of pork loin for consumers are related to food safety. Improvements in product image are the main subject to boost this supply chain. To better attend the demand, it is also important to offer a juicier and less fibrous product presented in fractional portions that are easier to prepare.

Improvements should be made in the different procedural stages that comprise these supply chain. For the production sector, animal management, genetic selection, and feeding are associated with final product quality, as well as animal welfare practices for transportation and slaughter. Those factors directly affect the pork loin's $\mathrm{pH}$, which means that the procedural priorities are linked to the attributes that consumers consider important.

The negative product image that leads people to believe that pork is unhealthy should be minimized through educational campaigns in supermarkets and media, highlighting the nutritional aspects and quality standards adopted by the industry.

\section{Acknowledgments}

Funding for this research was provided by Conselho $\mathrm{Na}$ cional de Pesquisa (CNPq) and Coordenação de Aperfeiçoamento de Pessoal de Nível Superior (CAPES), Brazil.

\section{References}

AASLYNG, M.D., Oksama, M., Olsen, E.W., Bejerholm, C., Baltzer, M., Andersen, G., Bredie, W.L.P., Byrne, D.V., Gabrielsen, G. (2007). The impact of sensory quality of pork on consumer preference. Meat Science, 76(I), 6I-73.

AKAO,Y. (1972). New product development and quality assurance deployment system. Standardization and Quality Control, 25(4), 243-246.

ALONSO,V., Campo, M. Del Mar., Laura, P., Roncalés, P., Beltrán, J.A. (20I0). Effect of protein level in commercial diets on pork meat quality. Meat Science, 85(I), 7-14.

BARCELLOS, M.D., Krystallis, A., Saab, M.S.M., Kügler, J.O., Grunert, K.G. (20I la). Investigating the gap between citizens' sustainability attitudes and food purchasing behaviour: empirical evidence from Brazilian pork consumers. International Journal of Consumer Studies, 35(4), 39I-402.

BARCELLOS, M.D., Saab, M.S.M., Pérez-Cueto, F.A., Perin, M.G., Neves, M.F., Verbeke,W. (20I l b). Pork consumption in Brazil: challenges and opportunities for the Brazilian pork production chain. Journal on Chain and Network Science, I I (2), 99-I I4.
BEATTIE, V.E., O'Connell, N.E., Moss, B.W. (2000). Influence of environmental enrichment on the behavior, performance and meat quality of domestic pigs. Livestock Production Science, 65(I-2), $7 \mid-79$.

BECKER, T. Defining meat quality. In: KERRY, J., Kerry, J., Ledward, D. (2002). Meat processing: improving quality. Cambridge: Woodhead Publishing Limited and CRC Press LLC, 20-34.

BERTOLONI, W., Silveira, E.T.F., Ludtke, C.B., Andrade, J.C. (2006). Avaliação de diferentes híbridos suínos submetidos à insensibilização elétrica e gasosa (CO2). Parte I: mensuração de indicadores sanguíneos de estresse. Ciência e Tecnologia de Alimentos, 26(3), 564-570.

BEZERRA, J.M.M., Neto, A.C., Silva, L.P., Lui, J.F., Rodrigues, A.E., Martins, T.D.D.M. (2007). Caracterização do consumidor e do mercado da carne suína na microrregião de Campina Grande, Estado da Paraíba. Ciência Animal Brasileira, 8(3), 485-493.

BRASIL. (1996). Ministério da Agricultura e Abastecimento. Portaria no. 304, de 22 de abril de 1996. http://www.agricultura.gov.br [Accessed March 23, 20I3].

CANEVER, M.D. (2006). From Fork to Farm - Demand Chain Management in the Agro-food Business:With Application to the Rio Grande do Sul Beef Business. I. ed.Wageningen:Wageningen University, I66p.

CHENG, L.C., Scapin, C.A., Oliveira, C.A., Krafetuski, E., Drumond, F.B., Boan, F.S., Prates, L.R., Vilela, R.M.(1995). QFD: planejamento da qualidade. Belo Horizonte: Fundação Christiano Ottoni, 26Ip.

CRAWFORD, S.M., Moeller, S.J., Zerby, H.N., Irvin, K.M., Kuber, P.S., Velleman, S.G., Leeds, T.D. (20I0). Effects of cooked temperature on pork tenderness and relationships among muscle physiology and pork quality traits in loins from Landrace and Berkshire swine. Meat Science, 84(4), 607-6I2.

DEKKER, M., Linnemann, A.R. Product development in the food industry. (1998). In: JONGEN, W.M.F.; Meulenberg, M.T.G. Innovation of food production systems: product quality and consumer acceptance. Wageningen:Wageningen Press, pp. 67-86.

FARIA, I.G., Ferreira, J.M., Garcia, S.K. (2006). Mercado consumidor de carne suína e derivados em Belo Horizonte. Arquivo Brasileiro de Medicina Veterinário e Zootecnia, 58(2), $25 \mathrm{I}-256$. 
FARIAS. A.E.M., Brandão, P.A., Assis, D.Y.C., Costa Neto, J., Sobral, F.E.S., Freitas, M.R.V. (20I2). Estudo socioeconômico dos consumidores de carne suína em três municípios do sertão Paraibano. Acta Veterinaria Brasilica, 6(3), 199-203.

FERRARIO, M.N., Cunha, M.S. (20I2). Estrutura e renda familiar no Brasil. Ensaios FEE, 33(I), 123-142.

GARNIER, J.P., Klont, R., Plastow, G. (2003).The potential impact of current animal research on the meat industry and consumer attitudes towards meat. Meat Science, 63(I), 79-88.

GRUNERT, K.G. (2002). Current issues in the understanding of consumer food choice. Trends in Food Science \& Technology, I3(8), 275-285.

GRUNERT, K.G. (2006). Future trends and consumer lifestyles with regard to meat consumption. Meat Science, 74(I), 149-160.

ITO, D. (2009). Desenvolvimento de materiais de embalagens para forno de microondas. Boletim de tecnologia e desenvolvimento de embalagens, 2 I (2), I-3.

JAISWAL, E.S. (2012).A Case Study on Quality Function Deployment (QFD). Journal of Mechanical and Civil Engineering, 3(6), 27-35.

KERRY, J.P., O'Grady, M.N., Hogan, S.A. (2006). Past, current and potential utilization of active and intelligent packaging systems for meat and muscle-based products:A review. Meat Science, 74(I), II3-130.

MIGUEL, A.C.A., Spoto, M.H.F., Abrahão, C., Silva, P.P.M. (2007). Consumer profile evaluation by quality function development for a pineapple. Ciência e Agrotecnologia, 3 I (2), 563-569.

O'CONNELL, N.E., Beattie,V.E., Moss, B.W. (2004). Influence of replacement rate on the welfare of sows introduce to a large dynamic group. Applied Animal Behaviour Science, 85(I-2), 43-56.

OIE - World Organization for Animal Health (2009). Joint $\mathrm{FAO} / \mathrm{WHO} / \mathrm{OIE}$ Statement on influenza $\mathrm{A}(\mathrm{HINI})$ and the safety of pork. http://www.oie.int/eng/press/en090507_bis. htm [Accessed May 25, 2013].

OIE - World Organization for Animal Health (201I). Terrestrial Animal Health Code. I, 20.Ed. Paris: France. http://www. oie.int/doc/ged/DI0905.PDF [Accessed June 07, 2013].
PARDI, M.C., Santos, I.F., Souza, E.R., Pardi, H.S. (200I). Ciência, higiene e tecnologia da carne. Goiânia: UFG.

POULSEN, C.S., Juhl, H.J., Kristensen, K., Bech, A.C., Engelund, E. (1996). Quality guidance and quality formation. Food Quality and Preference, 7(2), I27-135.

SANTIAGO, J.C., Caldara, F.R., Santos, V.M.O., Seno, L.O., Garcia, R.G., Almeida Paz, I.C.L. (20I2). Incidência da carne PSE (pale, soft, exsudative) em suínos em razão do tempo de descanso pré-abate e sexo. Arquivo Brasileiro de Medicina Veterinária e Zootecnia, 64(6), 1739-1746.

SANTOS, T.M.B., Cappi, N., Simões, A.R.P., Santos, V.A.C., Paiano, D., Garcia, E.R. (20II). Diagnóstico do perfil do consumidor de carne suína no município de Aquidauana-MS. Revista Brasileria de Saúde e Produção Animal, I2(I), I-I3.

SCHLINDWEIN, M.M., Kassouf, A.L. (2006). Análise da influência de alguns fatores socioeconômicos e demográficos no consumo domiciliar de carnes no Brasil. Revista de Economia e Sociologia Rural, 44(3), 549-572.

SIJTSEMA, S., Linnemann, A., Gaasbeek, T.V., Dagevos, H., Jongen, W. (2002).Variables influencing food perception reviewed for consumer-oriented product development. Critical Reviews Food Science and Nutrition, 42(6), 565-58I.

SILVA, I.J.O., Pandorfi, H., Piedade, S.M.S. (2008). Influência do sistema de alojamento no comportamento e bem-estar de matrizes suínas em gestação. Revista Brasileira Zootecnia, 37(7), 1319-1329.

SILVA, J.P., Silva, L.P.G. (2009). Estudo e Avaliação do Consumidor de Carne Suína "In Natura" e Industrializada na Microrregião de Guarabira - PB. Agropecuária Científica no Semi-Árido, 5, 57-6I.

VERBEKE, W. Pérez-Cueto, F.J.A., Barcellos, M.D., Krystallis, A., Grunert, K.G. (20I0). European citizen and consumer attitudes and preferences regarding beef and pork. Meat Science, 84(2), 284-292.

ZANELLA,A.J., Broom, D.M., Hunter, J.C., Mendl, M.T. (1996). Brain opioid receptors in relation to stereotypes, inactivity, and housing in sows. Physiology \& Behavior, 59(4-5), 769-775.

ZAREI, M., Fakhrzad, M.B., Paghaleh, J. (20II). Food supply chain leanness using a developed QFD model. Journal of Food Engineering, 102(I), 25-33. 